\title{
Turnover And Closed-End Fund Discounts
}

Jon Hooks, Albion College, USA

Sarah Erdman, Ernst and Young, USA

\begin{abstract}
This paper seeks to further investigate the quandary of closed-end fund discounts known as the "four-piece puzzle." While other researchers have taken a behavioral approach (investor sentiment, etc.), this study will explore empirical data on several variables, including some FamaFrench factors. Using a fixed effects model, the effects of turnover, three-year-beta, price/book, median market capitalization, expenses and income were measured in this study.
\end{abstract}

Keywords: Closed-End Fund; Turnover; Net Asset Value; Discount

\section{INTRODUCTION}

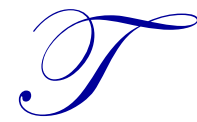

he hypothesis of this study is that an increase in turnover, price/book, three-year beta, or median market capitalization should result in an increase in the discount of the fund. This is because increased turnover increases the expenses of the fund (manager's fees, taxes, etc.) while, on average, it does not increase the value of the fund significantly (professional investors normally do not beat the market). The theory behind the price/book hypothesis is that a higher price/book can signal to investors that the fund is overvalued, so the demand for the fund will decrease and therefore the fund will sell at a discount. The findings support the hypothesis that turnover and price/book both impact the discount of closed-end funds as expected, with the statistical significance of price/book weaker. Neither three-year beta nor median market capitalization were found to have a statistically significant effect on discount.

\section{LITERATURE REVIEW}

One of the greatest mysteries in finance is the phenomenon of discounts in closed-end funds. This is known as the "four-piece puzzle." The first piece of this puzzle is that closed-end funds start out at a premium, which is mostly due to the underwriting and start-up costs incorporated into the share-price but not in the NAV. The perplexing part of this first piece is that investors are willing to pay a premium for new funds while existing funds trade at a discount. The second piece of this puzzle is that closed-end funds lose their premium and fall to a discount within 120 days from the beginning of trading; thereafter, discounts persist. The third piece of the puzzle is that the discounts fluctuate greatly over time (it is not a constant fraction of NAV). The final piece is that when closed-end funds announce that they will open-end or liquidate, share prices rise and discounts narrow. However, the discount doesn't completely disappear until final termination or open-ending (Lee, Shleifer \& Thaler, 1991).

Many different papers have been written to try to explain this phenomenon. Some standard explanations for the discount in closed-end mutual funds are agency costs, illiquid assets, and taxes. Agency costs are those due to overly high management fees and/or sub-par expected management performance. Illiquid assets can explain the discount in two different ways. First, mutual funds' NAV may overstate the true value of their assets because they hold significant amounts of restricted stock. Restricted stock has a lower market value and unrestricted stock, so this would lower the NAV if the NAV was estimated with unrestricted stock's NAV. Second, mutual funds may hold large amounts of individual securities, so the realizable proceeds from liquidation will be smaller than the value of a marginal share, which NAV is based on. Finally, taxes could explain the discount because the reported NAV values do not reflect capital gains taxes that are due in the event of liquidation. Therefore, the tax liability from assets that have appreciated would lower the share price below NAV (Lee, Shleifer \& Thaler, 1991).

Lee et al. (1991) proposed that investor sentiment, individual investor sentiment, and limited arbitrage are behind the closed-end fund discount. The investor sentiment explanation is that funds get issued when investors are 
optimistic and discounts change as sentiment changes. Because individual investors own a disproportionate amount of closed-end funds to the funds' assets, their irrational sentiment is likely to drive discounts. Finally, limited arbitrage explains in three reasons why mispricing can persist (and hedging doesn't persist with the mispricing of closed-end funds).

Anderston et al. (2013) further investigated the behavioral framework proposed by Lee by researching the effects of implied market volatility. They found that VIX has a small role in determining discounts except during periods of extreme market instability.

Recently, many researchers have focused on Lee's theories on investor sentiment. Chen, Johnson and Lin (2009) studied the effects of information asymmetries on investor sentiment. They focused on the differences between US and Taiwanese closed-end fund investors and found substantial differences. They found that Taiwanese investors sell their shares rather than hold them when Taiwanese closed-end funds announce that they are openending. However, foreign investors in Taiwanese closed-end funds do not sell their shares and make a profit when the fund open-ends.

Other researchers have studied investor sentiment by studying price fluctuations around newsworthy events. Burch, Emery and Fuerst (2003) observed that discounts worsened following September 11, 2001, and Hwang (2011) recently found evidence relating discount fluctuations to the German reunification and the Iraq war.

With all of the recent research, investor sentiment seems to be a strong theory with closed-end fund discounts. However, a recent Canadian study by Ayadi et al. (2011) found that consumer sentiment has no impact on discount, so it is difficult to conclude the actual effects of investor sentiment.

There has also been recent research in non-behavioral approaches. Dimson and Minio-Kozerski (2002) investigated the Fama-French factors. They found these factors (equity market, small firm, and book-to-market factors) explained closed-end fund share prices and NAV returns, but not discount changes. However, the authors did find that the sector, mean-reversion, manager and performance factors help explain changes in the discount. Berk and Stanton (2007) also concluded that managerial ability impacts the discount.

\section{THEORY}

The authors propose that none of the previously mentioned factors fully explain all four parts of the puzzle. This paper will investigate the importance of several factors on the discount of closed-end funds - turnover, threeyear-beta, median market cap, and price/book. Increased turnover yields increased brokerage costs and taxes, while no evidence exists to suggest that professional investors can beat the market (Malkiel, 2003). Therefore, the authors' theory is that these increased expenses without significant returns will decrease the value of the fund and result in the persistent discount. Malkiel (1977) found that the difference in manager fees did not significantly change the level of the discount, so the authors' theory is that while manager fees alone don't change the discount, manager fees and a large turnover do. This theory is supported, in part, by Kumar and Noronha (1992) who found that differences in fees do explain a small proportion of the cross-sectional variation in discounts (Dimson \& Minio-Kozerski, 2002).

Another possible source of the discount is the measure of the fund's three-year-beta. An increase in the volatility of the fund will create uncertainty, which devalues the fund. Therefore, one with a higher three-year-beta should have a larger discount.

Finally, the effect of price/book is examined. Some investors think that funds with a high price/book are overvalued which yields to demand for the fund decreasing, so the market price will decrease, resulting in a discount.

\section{DATA AND METHODS}

Data for this analysis is from Morningstar Principia and ranges through the years 1994-2010. The data are composed of information from all domestic equity closed-end funds that were started before 1990 and had not open- 
ended by 2010. The data set was limited for several reasons: 1) this specific data set has never been studied before and 2) the authors did not include any open-ended funds in order to avoid a bias, as they clearly revert to NAV at opening. By limiting the funds in this way, an attempt was made to limit the number of possible effects on discount. The variables investigated in this study and their definitions are listed in Table 1.

Table 1: Data Definitions

\begin{tabular}{|l|l|c|c|}
\hline Variable & Definition & Mean & Standard Dev. \\
\hline Market Price & Price of the fund in the market & 17.5269 & 13.9976 \\
\hline Net Asset Value & $\begin{array}{l}\text { Sum of the value of all of the investments in the fund } \\
\text { minus the fund's expenses }\end{array}$ & 18.4015 & 14.2974 \\
\hline Price Discount & Market Price - NAV & 0.8746 & 2.8660 \\
\hline 3-Year Beta & $\begin{array}{l}\text { Measure of volatility in the fund's market price over } \\
\text { three years }\end{array}$ & 0.9244 & 0.2703 \\
\hline $\begin{array}{l}\text { Median Market } \\
\text { Capitalization }\end{array}$ & Average size of equity holdings & 18656.85 & 18578.82 \\
\hline Price/Book & Market Price - Book Value & 3.3186 & 1.3962 \\
\hline Turnover & Number of times a fund buys/sells stock & 56.0738 & 52.7277 \\
\hline Income & Income/NAV & 1.3311 & 1.4563 \\
\hline Expense & Expenses/NAV & 1.0340 & 0.3927 \\
\hline
\end{tabular}

To test the hypothesis, the effect of turnover was found by regressing the discount with turnover, price/book, median market cap, and three year beta. However, the omitted variable test resulted in the conclusion that there were omitted variables, so other variables that were thought to have significance were added. These variables are the median market cap, price/book and three year beta. Testing for omitted variables resulted in the conclusion that there were omitted variables so the regressions should be run with either fixed effects or random effects. The Hausman test led to a significant coefficient, so regressions were done using fixed effects instead of random effects. Finally, the model was run robustly to correct for heteroscedasticity.

\section{RESULTS}

The variables, with their perspective statistics and significance of statistics, are shown in Table 2 . The only significant variable is turnover, with significance at a $5 \%$ level. No other variables are significant enough to take into account. However, the coefficient of turnover is small, meaning that it does not alone explain the discount.

Table 2: Regression Results

\begin{tabular}{|l|c|c|}
\hline Variable & Effect on Discount & P-Value \\
\hline Turnover & 0.0080 & .030 \\
\hline Expense & 0.1838 & .788 \\
\hline 3-Year Beta & 0.5606 & 0.561 \\
\hline Median Market Cap & 0.0000 & 0.910 \\
\hline Price/book & 0.2021 & 0.194 \\
\hline Income & 0.1813 & 0.121 \\
\hline
\end{tabular}

Because this theory is that turnover increases expenses, the authors correlated turnover and expenses to insure there was no co-linearity. The correlation of the two variables was very low $(0.1814)$, so there is no significant co-linearity in the model. However, the fact that expenses is not significant does not discredit the theory that turnover increases discounts. First, there are other factors that influence expenses, so any changes in those can change the impact of the variable. Additionally, assuming investors are rational, they would view an increase in turnover as a sign that the fund will perform poorly (since professional investors do not normally beat the market). Therefore, the demand for the fund will decrease, resulting in a decrease in market price, which yields the discount.

\section{CONCLUSIONS \& LIMITATIONS}

Turnover was found to have a significant effect on the discount of closed-end funds. Additionally, price/book was found to have an impact on the discount, but the statistical significance of this impact was weak. 
While the results for turnover were significant, the coefficient of turnover is small, so this means that turnover and price/book alone cannot explain all of the discounts or all parts of the four-piece. For instance, it cannot explain why the discounts tend to decrease before funds open-end (assuming the turnover rate does not change). Therefore, there must be variables that affect discount and were not included in this study.

A limitation of this study was that the sample size was rather small (around 180). It would be beneficial for this experiment to be conducted on a larger sample size. Additionally, a variable for management tenure would be valuable as the turnover theory is, in part, dependent on the reputation of the manger.

\section{AUTHOR INFORMATION}

Jon A. Hooks Ph.D., CFA, is chair and professor of economics and management at Albion College and is a CFA Charterholder. Dr. Hooks received his Ph.D. in monetary and financial theory from Michigan State University.

Sarah Erdman is a graduate of Albion College with majors in mathematics and economics. She is employed as an analyst at Ernst and Young in Dallas Texas.

\section{REFERENCES}

1. Anderson, S., Beard, T. R., Kim, H., \& Stern, L. V. (2013). Fear and closed-end funds. Applied Economic Letters, 20(10), 956-959.

2. Berk, J. B., \& Stanton, R.H. (2007). Managerial Ability, Compensation, and the Closed-End Fund Discount. Journal of Finance, 62, 529-56.

3. Burch, T. R., Emery, D. R., \& Fuerst, M. E. (2003). What can "nine-eleven" tell us about closed end fund discounts and investor sentiment? The Financial Review, 38, 515-529.

4. Chen, L.-W., Johnson, S. A., Lin, J.-C., \& Liu, Y.-J. (2009). Information, sophistication and foreign versus domestic investors' performances. Journal of Banking and Finance, 33, 1636-1651.

Dimson, E. \& Minio-Kozerski, C. (2002). A factor model of the closed-end fund discount. Working Paper. London Business School,

5. Hwang, B.-H. (2011). Country-specific sentiment and security prices. Journal of Financial Economics, $100,382-401$.

Kumar, R., \& Noronha, G. M. (1992). A re-examination of the relationship between closed-end fund discounts and expenses, Journal of Financial Research, 15, 139-147.

6. Lee, C., Shleifer, A. \& Thaler, R.H. (1991). Investor sentiment and the closed-end fund puzzle. The Journal of Finance, 46 (1), 75-109.

7. Malkiel, Burton G. (2003). Passive Investment Strategies and Efficient Markets. European Financial Management, 9 (1), 1-10.

8. Malkiel, B. (1977). The valuation of closed-end investment company shares, Journal of Finance, 32 (3), 847-859. 